\title{
Romersk-katolske sygeplejeordner i
Danmark efter reformationen
}

Af Susanne Malchau

Efter religionsfriheden var indfort, ankom de forste katolske søstre til Danmark $i$ midten af 1800-tallet med det formail at bygge et sygehus. Hoordan kom denne indsats $i$ stand $i$ et samfund, hvor der var et udtalt forbehold overfor alt katolsk? Hvad skete der $i$ modet mellem katolsk filantropi og opbygningen af protestantisk velfard?

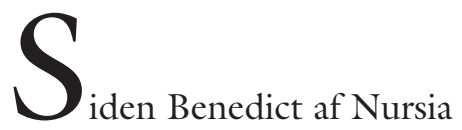

grundlagde det vestlige klostervæsen i 500tallet, har der været en uafbrudt forbindelse mellem nonners virke og omsorgen for samfundets fattige, syge og nødlidende. Den forbindelse blev styrket i 1600-tallet og fremover gennem grundlæggelsen af en række aktive og udadrettede sygeplejeordner såsom Vincent de Pauls Barmhjertige Søstre, der kom til at stå bag de første initiativer til en faglært sygepleje. I udforskningen af sygeplejens historie er dette bidrag til fagets professionalisering stort set forbigået. Historiens fokus har været den verdslige sygeplejetradition, personificeret gennem Florence Nightingale, der opfattes som den moderne sygeplejes grundlægger (Nelson 2001). ${ }^{1}$ Den opfattelse gxlder internationalt såvel som inden for danske rammer. Særlig velkendt er det ikke, at katolske sygeplejeordner - selv i protestantiske Danmark - har haft betydning for sygeplejefagets professionalisering og etableringen af det sundhedsvæsen, vi kender i dag. 
I Danmark har der siden 1856 i alt været 27 katolske nonne- og søsterordner. ${ }^{2}$ De kom alle fra udlandet udsendt af moderhuse fortrinsvis fra den katolske del af Europa. I 1856 ankom de første fire søstre og i 1940erne nåede antallet af nonner/søstre sit maksimale på 872 fordelt på 14 ordner. Siden har antallet af søstre været nedadgående, men nye ordner har fortsat etableret sig. Ved årtusindskiftet var der 239 katolske nonner/søstre i Danmark fordelt på 19 ordenssamfund (Malchau og Nilsen 2004). Hovedparten af søstrene har tilhørt ordner med et aktivt apostolat inden for sygepleje og undervisning.

Min baggrund for at tage dette emne op er et igangværende bogprojekt om religiøse søsterordners sygepleje og sygehuse i Danmark. ${ }^{3}$ Projektet dækker perioden 1856 1994, hvor første årstal markerer de første katolske søstres ankomst til Danmark efter reformationen og sidste årstal lukningen af det sidste religiøse sygehus. Projektet inkluderer otte søsterordner: Seks katolske som ejede 16 sygehuse og to diakonissehuse som ejede to sygehuse. Disse søsterordner har tilsammen stået bag en omfattende filantropisk indsats i det danske samfund, men til trods herfor er de stort set ukendte i dag og tillige overset i den hidtidige historieskrivning. 4

Antagelsen er, at religiøse søsterordner gennem deres sygehuse har stået bag et væsentlig bidrag i opbygningen af det sundhedsvæsen, der kom til at kendetegne den danske velfærdsstat. Men spørgsmålet er: Hvad der skete i mødet mellem en protestantisk velfærdsstat og en kristen (overvejende katolsk) filantropi? I dag er det åbenlyst, at udviklingen i det danske samfund gik den vej, at velfærdsstaten tog over og den filantropiske indsats måtte vige. Men forud og specielt i den periode velfærdsstaten etablerede sig, må søstrenes indsats have haft betydning. Et væsentligt spørgsmål i denne sammenhæng er, hvordan søstrene samarbejdede med de danske myndigheder og hvordan de integrerede sig i det danske samfund? Foregik det i en tilstand af konflikt eller konsensus mellem parterne - eller begge dele? 5

Her afgrænses til at vise omfanget af de katolske ordners indsats inden for dansk sygepleje og sygehusvæsen, og hvordan de blev modtaget i det lutheranske Danmark, der var yderst forbeholdent overfor det katolske. Dette gøres i et komparativt perspektiv med deres protestantiske pendant de danske diakonisser.

Men først en introduktion af Danmark i sidste halvdel af det 19. årh. med fokus på de katolske sygeplejeordners etablering i landet og møde med et offentligt sundhedsvæsen i sin vorden.

\section{SANKT JosepH SøSTRENES ANKOMST}

Ved reformationen 1536 fulgte Danmark Martin Luthers lære, og lutherdommen blev landets eneste tilladte religion - katolicismen var afskaffet. Luther tog som de øvige reformatorer afstand til klostervæsenet og følgen blev, at klostervæsenet blev afviklet i Danmark. Landets munke og nonner forsvandt og med dem tidens eneste eksisterende forsorgsarbejde for fattige, syge og nødlidende. Socialt arbejde blev lagt ud til sognene og beslaglagte klostre blev i nogle tilfælde anvendt til fattige og syge (Lausten 1987). Konsekvensen for omsorgen for samfundets svageste antages at være stor, så stor at de efterfølgende 300 år i sygeplejefaglig sammenhæng betegnes "sygeplejens mørke periode" (Gøtzsche og Nygaard 1993). ${ }^{6}$

Med grundloven 1849 blev der indført religionsfrihed i Danmark, og der var nu åbnet mulighed for en genetablering af den romersk-katolske kirke i landet. I grundloven blev borgernes fulde religionsfrihed fastslået, men også at den evangelisk-lutherske kirke var Danmarks Folkekirke og understøttes som sådan af staten (Lausten 1987).

Siden 1674 havde den romersk-katolske kirke haft tilladelse til et begrænset virke $\mathrm{i}$ 
Danmark, fordi landet rent politisk havde brug for gesandtskaber fra katolske lande. Da religionsfriheden var en realitet 1849, fik den bestående beskedne katolske menighed med få præster ret til at udvikle missionen, og det bestod bl.a. i at fă ordenssamfund til landet. Optakten begyndte i København i 1847-48, hvor den katolske Count Ferdinand Costa de Beauregard var udstationeret som Sardiniens chargé d'affaires. Han ansatte den danske og protestantiske lærerinde Marie Lohse som guvernante for sine børn. Hun blev grebet af det katolske, og under et ophold i Savoyen konverterede hun, og samtidig stiftede hun bekendtskab med ordenssøstre og deres arbejde med børn og syge. Det gjorde stort indtryk, og hun fik ideen, at en sådan orden ville være en hjælp til fremdriften af den katolske mission i Danmark. Ved hjemkomsten formidlede hun entusiastisk ideen:

"Med stor Iver oprullede hun for Dem alt det gode, som disse Søstre kunde udrette i Danmark saavel blandt Protestanter som blandt Katholikker. Tænke sig: Ordenssøstre til at undervise Børnene, til at besøge og pleje de syge, til at bringe Hjxlp til de fattige, til at trøste de betrængte sjæle, til at vejlede de søgende Sjæle, saa de kunde finde Vej til Moderkirken!” (De Beauregard 1944, 22).

Hun fik formidlet ideen, og der blev rettet henvendelse til en sygeplejeorden svarende til Vincent de Pauls Barmhjertige Søstre. Henvendelsen gik til Sankt Joseph Søstrene af Chambéry ${ }^{7}$ i Savoyen, og de blev spurgt, om de ville påtage sig at administrere og betjene et sygehus i København, som man påtænkte at oprette. Sankt Joseph Søstrenes generalpriorinde Mére Marie-Félicité indvilligede og sendte fire søstre til Danmark i den forståelse, at midlerne til deres underhold og sygehuset var sikret. De ankom med skib til København en kold majmorgen 1856 - og satte fod i et land, hvor de hverken kendte sprog eller kultur. Kun en ting vidste de: Danskerne havde et udtalt forbehold over for alt katolsk, og derfor bar de civilt tøj. Kulden gjorde dog, at der ikke gik mange dage før den uldne og varme ordensdragt kom på igen, og de måtte så lære at leve med den opmærksomhed, de vakte i bybilledet og gadedrengenes smæderåb. Desværre ankom de også til en katolsk menighed, der var totalt blottet for midler. Arrangementet var i virkeligheden en stor misforståelse. I Savoyen havde man forstået, at oprettelsen af det påtænkte sygehus var den danske missions anliggende, mens præsterne i Danmark havde forstået, at søstrene selv medbragte midler til eget underhold, samt til opførelse og indretning af et sygehus (Malchau 1998, Werner 2002, De Beauregard 1944).

Sygehusplanerne kunne ikke gennemføres og kirkens præster kom derfor til at se søstrene som endnu en udgift for den ubemidlede kirke. ${ }^{8}$ De vendte sig imod dem og brugte en mangfoldighed af argumenter for at få dem sendt hjem igen. I en henvendelse til ærkebispen i Chambéry anførte de, at søstrene ikke kunne lære det danske sprog og at deres ordensregel gjorde dem ubrugelige til ambulant sygepleje. "Deres nærværelse er til skade for dem selv, for deres personlige karakter, for kongregationens xre, for kirkens ry $\mathrm{i}$ almindelighed og for missionen i særdeleshed".9 Ærkebispen afviste og bad i skarpe vendinger præsterne om at hjælpe søstrene. ${ }^{10}$ Det økonomiske spillede hovedrollen i denne sag, men en vis afstandtagen til franske søstre spillede også ind. Missionens tyske prxst ville nemlig helst have barmhjertige søstre fra eget hjemland. Han mente de bedre kunne føle sig hjemme "blandt vore lave befolkningsklasser" end franske søstre, hvis kundskaber begrænsede sig til "kvindelige håndarbejder og kunstige blomster". 11 Det skulle dog vise sig, at søstrene havde talent for mere end kunstige blomster, netop Sankt Joseph Søstrene blev med tiden et stort aktiv for den katolske kirke i Danmark.

Søstrene var dog i første omgang overladt til egen skæbne, og at de forblev i 
Falleskursus for katolske søstersygeplejersker på Sankt Josephs Sygeplejeskole 1952 (Sankt Joseph Søstrenes arkiv, København) 
Danmark skyldtes, at konverterede kvinder fra det bedre borgerskab fik stor sympati for dem og støttede dem økonomisk og ved at skaffe dem arbejde. Søstrene fandt fodfæste og deres første boliger - fire kælderværelser på Sankt Annæ Plads og en lejlighed i Blancogaden [Fredericiagade] blev 1859 erstattet gennem køb af ejendommen Toldbodvej 14 [Esplanaden]. De følgende årtier blev søsterskaren øget via moderhuset og gennem danske indtrædelser. Ordenen grundlagde nye huse i provinsen, hvor søstrene underviste og plejede syge i hjemmene. I København åbnede de skoler, pensionater og børnehjem. Men først i 1875 fik de opfyldt målet med at komme til Danmark. På dette tidspunkt havde de fået indsamlet midler til at opføre og åbne landets første katolske sygehus, Sankt Josephs Hospital i Griffenfeldtsgade i København. I løbet af de næste 25 år grundlagde de yderligere syv sygehuse i landets større provinsbyer, og alle kom til at bære navnet Sankt Josephs Hospital (De Beauregard 1944, Malchau 2003, Werner 2002). 12

Sankt Josephs hospitalernes grundlæggelse faldt ikke helt tilfældigt sammen med, at det danske sygehusvæen var i en rivende udvikling. Den tid var forbi, hvor sygehuse kun havde til opgave at isolere patienter med smitsomme sygdomme og fungere som plejeinstitutioner for fattige. Befolkningen var begyndt at bruge sygehusene mere end tidligere, og en væsentlig grund var medicinens udvikling, selvom muligheden for behandling stadig var begrænset. Pasteurs opdagelse af bakterien gav nye muligheder i behandlingen af smitsomme sygdomme, og kirurgien havde med kloroform og xter fået midler til bedøvelse. Lægerne havde brug for sygehuse som behandlings-, forsknings- og undervisningsinstitutioner, og befolkningen havde brug for dem grundet tidens sociale forandringer med tilvæksten af en lønarbejderklasse, der ofte stod uden hjælp og forsørgelse ved sygdom. På baggrund heraf op- stod et behov for moderne og teknologisk veludstyrede sygehuse samt et faguddannet sygeplejepersonale, der kunne assistere lægerne på kvalificeret vis og observere patienterne døgnet rundt (Vallgårda 1985). En mangfoldighed af nye offentlige sygehuse blev opført, men efterspørgsel og udbud hang tilsyneladende ikke sammen. Der var også behov for de sygehuse, religiøse søsterordner tilbød at grundlægge. Adskillige katolske sygeplejeordner fulgte Sankt Joseph Søstrene og dertil kom diakonissehusenes indsats inden for samme felt.

\section{KATOLSKE SØSTRE I DANSK SYGEPLEJE}

Yderligere ni kvindelige katolske ordener med sygepleje som virkefelt kom til Danmark (tabel 1). Fire af disse ordner byggede ikke sygehuse, men beskxftigede sig på anden vis med sygepleje. Det var Søstrene af det Dyrebare Blod, der beskxftigede sig med socialt-karitativt arbejde. Ursulinerinderne fra Bielefeld havde rekreationshjem, og Sankt Vincent Søstrene beskæftigede sig med hjemmesygepleje. Endelig har Benediktinerinderne af den Hellige Lioba beskxftiget sig med hjemmesygepleje og drevet plejehjem (Katholsk Haandbog 1943, De kvindelige ordenssamfund 2001). Antallet af søstre i disse ordner har altid været begrænset, men kun en af ordnerne har forladt landet igen. I 1960 opnåede de deres maksimale antal søstre på 53, i dag er der 26 (tabel 1) (Malchau og Nilsen 2004).

De resterende fem kvindelige katolske sygeplejeordner grundlagde otte katolske sygehuse, ét i København og de øvrige i provinsen (tabel 1). De ankom i perioden 1895-1931, og to af ordnerne har forladt landet igen. Sankt Elisabeth Søstrene fra Tyskland åbnede to sygehuse, Elisabethinersøstrene fra Polen et sygehus, Sankt Hedvig Søstrene fra Polen to sygehuse, Mariasøstrene fra Belgien to sygehuse og Visdomsdøtrene fra Frankrig et sygehus. Endelig - og undtagelsen for reglen - kom et enkelt mandligt ordenssamfund Kamillia- 
Katolske sygeplejeordner med sygehuse

\begin{tabular}{|c|c|c|c|c|c|c|}
\hline 1880 & 1900 & 1920 & 1940 & 1960 & 1980 & 2000 \\
\hline \multirow[t]{6}{*}{64} & 200 & 407 & 524 & 409 & 250 & 85 \\
\hline & 11 & 40 & 66 & 75 & 30 & 11 \\
\hline & & 25 & 28 & 25 & 11 & - \\
\hline & & 43 & 114 & 113 & 53 & 24 \\
\hline & & 22 & 30 & 53 & 32 & 13 \\
\hline & & & 13 & 15 & - & \\
\hline
\end{tabular}

Sankt Joseph Søstrene 1856

8 sygehuse

Sankt Elisabeth Søstrene 1885

2 sygehuse

Visdomsdøtrene 1903-97

1 sygehus

Sankt Hedvig Søstrene 1906

2 sygehuse

Maria Søstrene 1911

2 sygehuse

Elisabethinerinder 1931-74

l sygehus

Katolske sygeplejeordner uden sygehuse

Sankt Vincent Søstrene 1904

Søstrene af det Dyrebare Blod 1916

Benediktinerinderne af den Hl. Lioba 1935

Ursulinerinder fra Bielefeld 1932-65

Totalt antal $i$ sygeplejeordner

Totalt antal $i$ øvrige katolske ordner

$\begin{array}{rrrrrrr} & & 6 & 8 & 7 & 6 & 4 \\ & & 8 & 6 & 16 & 13 & 11 \\ & & & 5 & 20 & 25 & 11 \\ & & & 10 & 10 & - & - \\ 64 & 211 & 551 & 804 & 746 & 420 & 159 \\ 0 & 18 & 87 & 68 & 79 & 84 & 80\end{array}$

Tabel 1: Søstre i katolske sygeplejeordner og ovrige katolske ordner i Danmark (Malchau og Nilsen 2004)

nerne fra Tyskland 1899 og åbnede et sygehus. ${ }^{13}$ Sankt Joseph Søstrenes hospitaler medregnet blev der samlet grundlagt 17 katolske sygehuse i Danmark i perioden 1875-1931 (Malchau 2003, Malchau og Nilsen 2004).

De katolske sygehuse begyndte oftest i beskedne lejede lokaler, men i løbet af få årtier udviklede de sig til store sygehuse med et betragteligt antal sengepladser. Sankt Josephs Hospital i København var mastodonten med op til 400 senge, men hospitalerne opnåede tilsammen op til 1.619 senge i 1940, heraf var 1.031 (49 procent) placeret på Sankt Josephs hospitalerne (Malchau 2003).

\section{DIAKONISSER I DANSK SYGEPLEJE}

De katolske søsterordner var som nævnt ikke de eneste kvindelige religiøse fællesskaber i Danmark, der havde sygeplejen som omdrejningspunkt. I samme periode de katolske ordner kom til landet stiftedes landets første diakonissehus. Det skete på foranledning af enkedronning Caroline Amalie, der ønskede daværende prinsesse Louise af Danmark i spidsen for et stort og velsignet foretagende. Prinsessen tog engageret opgaven på sig og blev stifter af Den danske Diakonissestiftelse, der blev åbnet 1863 i et lille hus i Smallegade i København, hertil hørte et sygehus med ganske få senge. Efter nogle år var institutionen så velfungerende, at en udvidelse var nødvendig og 
1876 indviedes en ny stiftelse på Peter Bangsvej på Frederiksberg, herunder et nyt sygehus med 60 senge (Hauge 1963).

Forbilledet for Diakonissestiftelsen var diakonissehuset i Kaiserswerth, grundlagt 1836 af pastor Theodor Fliedner, og efter samme forbillede blev yderligere to diakonissehuse i Danmark grundlagt. I 1900 kom Diakonissehuset Sankt Lukas Stiftelsen til med filantropen Isabelle BrockenhuusLöwenhielm som stifter. Huset havde først til huse på Nørre Allé i København, og her var der et sygehus på 56 senge. I 1932 flytter stiftelsen til Hellerup til et nyt hus og et sygehus på 150 senge (Malmgart 2000). Det sidste diakonissehus blev stiftet 1913 på Kolonien Filadelfia beliggende i Vestsjælland. Kolonien var grundlagt af 1897 af lægen Adolph Sell, som stod i spidsen for stedets sygehus for epileptiske patienter (Malmgart 1996).

Diakonissernes sygehusprojekt var ikke så omfattende som de katolske søstres. De grundlagde to somatiske sygehuse, som i lighed med de katolske begyndte i beskedne lokaler og efter samme mønster udviklede sig til store sygehuse. Tilsammen opnåede de op til 510 sengepladser med højdepunkt i 1970. Diakonissestiftelsen var mastodonten med mellem 250 og 300 sengepladser fra 1940-1970, mens Sankt Lukas Stiftelsen i samme periode havde ca. 170 senge (Medicinalberetninger 1900-1970).

\section{DET SAMLEDE RELIGIØSE SYGEHUSPROJEKT}

Diakonissehusene grundlagde to sygehuse og lægges de 17 katolske sygehuse til, blev der således opført 19 private religiøse sygehuse i Danmark fra 1875 til 1931. Men hvilken andel havde disse sygehuse så i det samlede sygehusvasen? Dette forhold vises i tabel 3, hvor diakonissernes og de katolske ordners sygehuses specifikke og samlede andel af landets sengepladser demonstreres fra 1900 til 1970.

Som det fremgår har diakonisserne med et sengetal fra 146 stigende til 510 kontinuerligt haft to procent af landet samlede sengepladser. At de fastholdt denne procentandel skyldtes, at de i modsætning til de katolske sygehuse øgede antallet af sengepladser i slutningen af perioden. Herefter faldt antallet hastigt og sygehusene var under afvikling fra 1970erne. Diakonissestiftelsens sygehus lukkede 1985 og Sankt Lukas Stiftelsens 1992. Som det fremgår var diakonissernes indsats $\mathrm{i}$ forhold til landets samlede sygehusvæsen altså begrænset. Grunden, som jeg vender tilbage til, var, at de af konfessionelle grunde kunne og åbenbart ville prioritere anderledes i deres samlede sygehus- og sygeplejeindsats end de katolske søstre.

De katolske ordners 17 sygehuses andel af landets sengepladser var mere markant. I perioden 1910-1940 havde de 937 stigende til 1.689 senge svarende til $9-10$ procent af landets sengepladser. Efter 1940 begyndte andelen af falde, og det viser, at afviklingen af disse sygehuse begyndte tidligere end afviklingen af diakonissernes sygehuse. Det første katolske sygehus lukkes 1946 og det sidste 1994, de fleste i perioden 196575. Samlet viser opgørelsen, at de katolske ordner ydede en betydelig større indsats på sygehusområdet end diakonisserne. Det skyldtes, at de næsten udelukkende prioriterede sygehusområdet. Den tidlige afvikling kan ses som en indikator for, at det danske sundhedsvæsen var mere interesseret $\mathrm{i}$ at blive de katolske sygehuse kvit end diakonissernes.

Samlet var diakonissernes og de katolske ordners indsats i sygehusvæsenet betragteligt. Med et sengeantal fra 1.108 stigende til 2.116 mellem 1910 og 1940 var 11-12 procent af sygehusvæsenets senge placeret på deres 19 sygehuse. De religiøse sygehuses storhedstid var 1930erne og 1940erne, hvor de havde 12 procent af sengepladserne. At procentandelen herefter faldt skyldtes i første omgang ikke, at antallet af senge blev formindsket, men at det offentlige sygehusvæsen var under udbygning og 
øgede sit sengetal betragteligt. Det var først fra 1960erne afviklingen af de religiøse sygehuse gik stærkt. Det skete i takt med at det offentlige sygehusvæsen blev udbygget, og velfærdsstaten etablerede sig.

I den periode det religiøse sygehusprojekt var i fuldt flor, skulle ordenerne forsyne et betragteligt antal sygehuse med kvalificerede søstersygeplejersker. Hvordan diakonisserne og de katolske søstre respektivt forvaltede dette, ses der på i det følgende.

\section{REKRUTTERING OG UDDANNELSE I SYGEPLEJE}

Diakonissehusene uddannede selv søstrene til sygeplejen på egne sygeplejeskoler. I 1863 var Diakonissestiftelsen det første sted i Danmark, hvor der blev etableret en formel sygeplejerskeuddannelse i teori og praksis. Diakonisserne var dog ikke de første faguddannede sygeplejersker i landet, for mange af de katolske søstre, der kom til landet, var uddannet i deres hjemland. ${ }^{14}$ I Danmark foregik deres uddannelse i første omgang på de enkelte ordner respektive sygehuse. Men da kravene til uddannelsen i 1930erne skærpedes i forbindelse med sygeplejefagets statsautorisation 1933, og da der i samme tid var der en skarp offentlig debat om de katolske sygehuses berettigelse i det danske samfund, åbnede de katolske sygeplejeordner i Danmark i 1936 en fælles sygeplejeskole ved Sankt Josephs Hospital i København. Hensigten var primært at sikre et højt, ikke kritisabelt fagligt niveau, men også at værne om de katolske værdier og sikre de katolske sygehuses overlevelse. Det faglige niveau lykkedes til fulde, for skolen placerede sig med Diakonissestiftelsens og Sankt Lukas Stiftelsens blandt landets bedste og mest visionære. Men på sigt lykkedes det alligevel ikke skolen at sikre opretholdelsen af de katolske sygehuse (Malchau 1998).

En del af Diakonissestiftelsens og Sankt Lukas Stiftelsens søstre virkede som sygeplejersker på institutionernes egne sygehu- se, men hovedparten blev udsendt til alle egne af landet, for at organisere sygeplejen på offentlige sygehuse og virke $\mathrm{i}$ menighedsplejen (Malmgart 2000). Det ser jeg som forklaringen på, at diakonissehusene ikke grundlagde flere private sygehuse i Danmark. Formålet med diakonissehusene var nemlig ikke at fastholde søstrene i moderhuset, men at udsende dem til steder, hvor der var behov for deres ekspertise. I modsætning hertil virkede de katolske søstre kun på egne sygehuse. Det skyldes, at deres ordensregler overvejende foreskrev, at de var klausuleret som nonner, sygehusets rammer var blot en udvidelse af den sædvanlige klosterklausur. Det betød, at katolske søstre frem til 1960erne, hvor kirken reformerede ordenslivet, stort set ikke arbejdede uden for egne institutioners mure, og det er sandsynligvis en del af forklaringen på, at katolske sygeplejeordner uden sygehuse havde så begrænset et virke. Dertil er det utænkeligt, at et offentligt sygehus i den tid ville ansætte en katolsk søster (Malchau 1998).

I sagens natur var der brug for et betragteligt antal søstre uddannet i sygepleje til det omfattende virke, de respektive ordener havde. Men hvor mange var der, og hvordan blev de rekrutteret? Som det ses i tabel 1 og 2 var der kontinuerligt samme antal diakonisser som katolske søstre knyttet til sygeplejeordner. For begge parter faldt det højeste antal af søstre ikke overraskende i 1940erne, hvor ordnerne ydede den største indsats. Her var der henholdsvis 819 diakonisser og 804 katolske søstre i sygeplejeordner. Hvor stor en andel de uddannede sygeplejersker udgjorde, er det vanskeligt at sige præcist ud fra det foreliggende kildemateriale. Både diakonisserne og de katolske ordner havde andre virkefelter end sygeplejen, specielt de katolske som havde omfattende skolevirksomhed. Det må dog antages, at en god part af søstrene var sygeplejersker, eftersom sygehusene frem til midten af 1900-tallet udelukkende var betjent af søstre (Malchau 1998). 
Den ligelige fordeling i antal af diakonisser og katolske søstre er overraskende. Det forventelige var, at antallet af diakonisser var højest, fordi de var danskere og i konsensus med landet konfessionelle tilhørsforhold den evangelisk lutherske kirke. I modsætning til de katolske søstre havde diakonisserne et naturligt grundlag for rekruttering $i$ Danmark. De katolske ordner var nødsaget til at rekruttere hovedparten af søstrene i udlandet, kun et fătal af danske piger indtrådte. Den rekruttering foregik via moderhusene i udlandet, fortrinsvis Frankrig, Tyskland og Polen (Malchau 2003).

Sankt Joseph Søstrene og Diakonissestiftelsen havde kontinuerligt næsten samme antal af søstre, begge parter omkring $500 \mathrm{i}$ 1940erne, dvs. totredjedele af det samlede antal søstre. Det skyldtes givet, at disse ordner var de første - og det indikerer desuden, at de fastholdt en postion som pionererne og de toneangivende.

Fra 1940erne faldt antallet af søstre, og det kan forklares ud fra to til dels overlappende synsvinkler. For det første begyndte velfærden at etablere sig. Det offentlige udbyggede sundhedsvæsenet og havde ikke brug for søsterordnernes hjælp mere. For det andet faldt tilgangen af nye søstre. Den i de katolske ordners terminologi såkaldte kaldskrise satte ind, og påvirkede i stigende grad både diakonissehusenes og de katolske ordners rekrutteringsgrundlag. Det betyder, at søstrenes gennemsnitlige alder i dag er meget høj, og ordnernes sociale og karitative aktiviteter er af den grund begrænset, selvom nye virkefelter stadig opdyrkes, f.eks. personlig og åndelig vejledning. 15

\section{ET TOSIDIGT MISSIONSPROJEKT}

Diakonisserne var i harmoni og konsensus med de danske myndigheder både $\mathrm{i}$ forhold til deres private sygehuse og deres religiøse tilhørsforhold, f.eks. omtalte medicinaldirektør Johannes Frandsen i 1934 dem som "vore egne" (Politiken 1934). Den betegnelse brugte han ikke om de katolske søstre. For ét var, at der var konsensus om deres sygehuse $\mathrm{i}$ forhold til pleje og behandling af de danske borgere, noget andet søstrenes religiøse tilhørsforhold - det katolske. Det var et konfliktfyldt farvand, hvor søstrene skulle træde varsomt.

"Søstrene havde nok fra første Færd besøgt de syge og plejet dem i disses Hjem; og de havde gjort den Erfaring, at dette var det bedste Middel til at komme de i Begyndelsen fjendtligt sindede Protestanter på nærmere Hold, befri dem for deres Fordomme og bane Vejen for dem til den sande Tro." (De Beauregard 1936, 101)

Citatet fra Sankt Joseph Søstrenes kronik demonstrerer, at sygeplejeordnerne havde et tosidigt formål med at etablere sig i Danmark. Det handlede på den ene side om at missionere for den katolske tro og på den anden side om på filantropiens grund at pleje syge.

Hvad angik formålet om, at omvende danskerne til den katolske tro lykkedes projektet ikke særlig godt. Kirken hentede mange ordensfolk til landet, så mange "[at] i forhold til antallet af katolikker var Danmark et af de lande i verden, der havde flest ordensfolk overhovedet! "(Katolsk haindbog 1983, 27). Netop den opgørelse viser, at det ikke lykkedes at omvende danskerne; en succesfuld mission havde medført en mere realistisk fordeling, altså færre ordensfolk. Antallet af katolikker var og forblev sparsomt i Danmark. I dag er der 35.000 og det 'høje tal' skyldes indvandring. I 1890 var der 3.000 og i 1943 22.000. I 1940erne udgjorde ordenssøstrene med et antal på 872 fire procent af landets katolikker (tabel 1) (Katolsk haindbog 1983).

Der kan med rette spørges, hvorfor den katolske kirkes øvrighed ikke prioriterede anderledes, da det var åbenbart at missionsprojektet ikke lykkedes? En del af forklaringen må være, at sygeplejeordnerne økonomisk var et aktiv for kirken og dertil - til tider til kirkens utilfredshed - var autonome i 
egne forhold. Det var nogle stærke, kvindelige kollektiver, der fastholdt deres egen agenda og den var i høj grad også knyttet til den del af det tosidede formål, der handlede om at hjælpe næsten. "[At pleje de syge er] en af de væesentligste gerninger, Søstrene skal paatage sig over for Næsten" (De Beauregard 1936, 101).

I dag vides det at missionsprojektet ikke lykkedes, men det vidste de danske myndigheder ikke, da det ene katolske sygehus efter det andet skød op i det danske landskab. Myndighedernes dilemma var, at de ønskede de katolske sygehuse, men ikke de værdier de repræsenterede.

Sagen var, at danskerne siden reformationen havde fået grundfæstet en kultur med udtalt skepsis og angst over for alt, hvad der havde med katolicismen at gøre. Det forhold ændrede religionsfriheden ikke på. Da de katolske søsterordner kom til landet, mødte de fra alle sider den holdning, at katolicismen var en trussel mod den nationale identitet, og det at gå i kloster var unaturligt. I en lutheransk kontekst var den højeste status en kvinde kunne få moderens/ hustruens, mens nonnen havde højest status i en katolsk kontekst. En kulturel og konfessionel forskellighed der gjorde, at den største skam en dansk familie kunne udsættes for var, at en datter konverterede og gik i kloster (Malchau 2004).

På dette grundlag er det ikke overraskende, at danskerne var mere end skeptiske over for søstrene, og de første årtier, de var i landet, udfoldede der sig en følelsesladet offentlig polemik om deres berettigelse i landet (Malchau 2003 og 2004).

Myndighederne løste i første omgang dette dilemma gennem skriftlige kontrakter med søstrene, hvor det var anført, at katolsk påvirkning af lutheranske patienter var strengt forbudt. Det indebar bl.a. forbud mod uddeling af katolske pamfletter, og mod katolske messer og kirker på sygehusene. Dertil skulle Folkekirkens præster altid havde adgang til indlagte lutheranere.

Danskerne, såvel som ansvarlige myndig- heder, var udmærket klar over, at disse forbehold ikke var tilstrækkelige til at undgå katolsk propaganda, for søstrenes livsform og fremtoning i ordensdragten var i sig selv en indirekte form for mission. I alle byer, 
Sankt Josephs Hospital i København 1905 (Sankt Joseph Søstrenes arkiv, København)

hvor søstrene slog sig ned, var den lokale befolkning derfor på vagt. Selv de mindste hændelser kunne udløse en offentlig polemik i dagspressen om "nonnernes propaganda", som man kaldte det, og bølgerne gik højt, når det handlede om en lutheransk pige, der konverterede og gik i kloster. ${ }^{16}$ At propagandaen også lykkedes kan, som beskrevet af Werner (2002), illustreres med det katolske sogn på Nørrebro i 
Operationsstuen Sankt Josephs Hospital København 1901 (Sankt Joseph Søstrenes arkiv, København)

København, der efter sigende blev grundlagt på basis af patienter, der konverterede efter at have været plejet af søstrene på Sankt Josephs Hospital.

Polemikken fortsatte $\mathrm{i}$ årtier og kulminerede 1934, da medicinaldirektør Frandsen nægtede at give Visdomsdøtrene tilladelse til at bygge endnu et sygehus. Hans projekt var at opbygge et velfungerende offentligt sygehusvæsen, og her havde han ikke brug for flere bidrag fra katolske ordner. Dog var hans afslag begrundet i konfessionelle synspunkter og ikke i organisatoriske eller faglige. 
Den katolske kirkes øvrighed og de katolske læger opfattede medicinaldirektørens udtalelse som en krigserklæring. En hurtig modstrategi var nødvendig. Lægerne mente, at de enkelte katolske hospitaler, der virkede uafhængigt af hinanden, skulle styrkes gennem samarbejde og sikring af den faglige standard. Der skulle arbejdes for en fælles front, så fremtidige angreb på forhånd kunne imødekommes. Derfor stiftes januar 1935 "Foreningen af Læger ved katolske Hospitaler i Danmark" og december samme år "Centralraadet for den katolske Hospitalsvirksomhed i Danmark". Begge foreninger indledte et nært samarbejde med de respektive ordners ledende søstre og blev på den måde bindeleddet mellem de katolske sygehuse. I 1949 styrkes denne strategi yderligere gennem oprettelsen af "Vikariatets Hospitalsudvalg", som varetog hospitalernes fælles interesser gennem bistand ved forhandlinger med offentlige myndigheder, ansættelse af ledende læger mv. Sygeplejefagligt blev denne kurs fulgt op i 1940 gennem stiftelsen af "Danmarks katolske Sygeplejerske-Forbund", hvor formålet var et åndeligt fællesskab med trosfæller i samme arbejde og vilkår. ${ }^{17}$ (Katolsk Ugeblad 1940).

Med disse initiativer måtte de enkelte søsterledelser nødvendigvis afgive noget af deres suverænitet. Samarbejde blev de følgende årtier en væsentlig nøgle for deres sygehuses overlevelse, og det gav kirken og lægerne øget indflydelse og magt vedrørende sygehusenes drift.

Medicinaldirektør Frandsens udtalelse, og de strategier den medførte for de implicerede parter, faldt på den tid de katolske sygehuse var på deres højdepunkt. Selv om

"For dem kommer Hensynet til Samfundet først efter Hensynet til deres Orden, og i sidste Instans faar de deres Direktiver fra Rom... Hospitalet er for de katolske Ordner kun et Virkefelt, og Maalet er at drive Propaganda, selv om den ikke giver sig direkte Udtryk." (Politiken 1934). de var velfungerende de følgende årtier, var det dog på dette tidspunkt kimen til afviklingen blev lagt. Frandsens strategi blev selvsagt den udslagsgivende, for det var ham der stod bag strategien for opbygningen af velfærdsstatens nye og udelukkende offentlige sygehusvæsen. De katolske institutioner var ikke medtaget her, og med ti- 


\section{Diakonissehuse}

Diakonissestiftelsen 1863

l sygehus

Sankt Lukas Stiftelsen 1900

l sygehus

Kolonien Filadelfia 1913

Total $\begin{array}{lllllll}1880 & 1900 & 1920 & 1940 & 1960 & 1980 & 2000\end{array}$

$\begin{array}{lllllll}76 & 269 & 350 & 459 & 350 & 250 & 81\end{array}$

$\begin{array}{llllll}5 & 128 & 292 & 259 & 169 & 70\end{array}$

$\begin{array}{lllll}39 & 68 & 54 & 39 & 10\end{array}$

$\begin{array}{lllllll}76 & 274 & 517 & 819 & 663 & 458 & 161\end{array}$

Tabel 2: Diakonisser i danske diakonissehuse (Malmgart 1996 og 2000, Hauge 1963)

$$
\begin{array}{llllllll}
1900 & 1910 & 1920 & 1930 & 1940 & 1950 & 1960 & 1970
\end{array}
$$

$\begin{array}{lcccccccc}\text { Offentlige } & 4.002 & 9.526 & 10.978 & 12.237 & 16.189 & 19.359 & 27.371 & 28.446 \\ \text { Sygehuse } & 92 \% & 90 \% & 89 \% & 88 \% & 88 \% & 91 \% & 93 \% & 95 \%\end{array}$

Sygehuse

Diakonisse

$146 \quad 17$

176

$$
230
$$

427

440

466

510

Sygehuse

$3 \%$

$2 \%$

$1 \%$

$2 \% \quad 2,5 \%$

$2 \%$

$2 \%$

$2 \%$

Katolske

$224 \quad 93$

1.185

$1.411 \quad 1.689$

1.466

1.539

867

Sygehuse

$5 \%$

$10 \%$

$10 \% \quad 9,5 \%$

$7 \%$

$5 \%$

$3 \%$

Totalt religiose

$370 \quad 1.108$

$1.361 \quad 1.641$

2.116

1.906

2.005

1.377

sygehuse

$8 \% \quad 11 \% \quad 11 \%$

$12 \% \quad 12 \%$

$9 \%$

$7 \%$

$5 \%$

Totalt

senge $i D K$

$\begin{array}{lll}4.372 & 10.634 & 12.339\end{array}$

13.878

18.305

21.265

29.376

29.823

Tabel 3: Religiøse sygehuses andel af somatiske sengepladser i Danmark 1900-1970

(Medicinalberetninger 1900-1970) 
den blev diakonissernes sygehuse også fravalgt. 18

\section{AfSLUTNING}

Afslutningsvis vil jeg konkludere, at katolske sygeplejeordner har ydet en betragtelig og betydeligt større indsats end diakonisserne i opbygningen af det danske sygehusvæsen. Indsatsen var af et sådant omfang, at den omfattede ti procent af landets sengepladser i perioden 1920-1940, og den må derfor anses som et væsentlig bidrag i opbygningen af den danske velfærdsstat. Til trods for dette var de katolske søstres tilstedeværelse i landet ikke særlig ønsket, men tolereret fordi landet havde brug for deres sygehuse. På den måde opstod der både konsensus og konflikt mellem de danske myndigheder og de katolske ordenssamfund. Konsensus, fordi begge parter arbejdede mod det samme gode mål, et velfungerende sygehusvæsen til gavn for alle borgere. Konflikt, på grund af konfessionelle forskelligheder - lutheranisme versus katolicisme. De katolske søstre fik professionel anerkendelse som veluddannede sygeplejersker og dygtige sygehusadministratorer, men som ordenssøstre var de anset som kulturelt fremmedartede i et dansk samfund, der insisterede på egne værdier kulturelt og religiøst.

I dag er de katolske sygeplejeordners æra i Danmark forbi og antallet af søstre hastigt nedadgående. De få nye kald til klosterlivet går til kontemplative ordner, som ved årtusindskiftet tegnede sig for 38 procent af søstrene (tabel 1). Den udvikling har sin forklaring i de vestlige samfunds udvikling, og i de reformer den katolske kirke er undergået. Det har medført ligestilling mellem kønnene og kvindens ret til selvbestemmelse over eget liv, og på den måde er klostertilværelsen ikke mere et attraktivt fristed for kvindelig intellektuel udfoldelse eller måden at undslippe patriarkatets fædre og xgtemand. Den udvikling er yderligere stimuleret af de reformer ordenslivet un- dergik med Det andet Vatikankoncil i 1960erne. Det var et moderniseringsprojekt, der ændrede struktur og livsform i aktive karitative ordner. Med et slag forsvandt det traditionelle klosterliv fra disse, men det gjorde det ikke i de kontemplative ordner. Den vestlige kvinde der vælger at gå i kloster i dag, vælger oftest det traditionelle klosterliv.

\section{NoTER}

1. Den moderne sygeplejes gennembrud bestod i, at de uuddannede vågekoner blev erstattet af borgerskabets dannede døtre, som gennemgik en formel uddannelse. I Danmark blev første initiativer til en sygeplejeuddannelse taget af Den danske Diakonissestiftelse 1863 og Københavns Kommunehospital 1876 (Gøtzsche og Nygaard 1993).

2. I romersk-katolsk kanonisk terminologi anvendes betegnelsen 'søster' om kvinder i kongregationer med et udadrettet apostolat som f.eks. sygeplejeordner. Betegnelsen 'nonne' anvendes om kvinder i klausulerede eller kontemplative/monastiske ordner (Carey 1997).

3. I projektet er kun inkluderet ordenssamfundenes somatiske (medicinsk-kirurgiske) sygehuse. De grundlagde også sanatorier og klinikker for lægers specialvirksomhed.

4. Det er først de senere år, nordiske forskere er begyndt at interessere sig for kvindelige katolske ordner inkl. deres sygepleje i moderne tid. F.eks. Werner 2002 og 2004, Malchau 1998 og 2003, Nilsen 2001.

5. Spørgsmålets teoretiske grundlag er Bundesen, Henriksen og Jørgensens (2001) model til analyse af forholdet mellem filantropi og stat ud fra synsvinklerne: Konflikt eller konsensus. Med konfliktmodellen menes, at en uafhængig filantropisk indsats underlægges staten, så der opstår et hierarki mellem parterne, staten har magten. Med konsesusmodellen menes, at den filantropiske organisation i samarbejde med staten arbejder mod det samme gode mål.

6. Fænomenet sygeplejens mørke periode (Dark Period in Nursing) er videreført i den danske litteratur fra den tidligste forskning i engelsk sygeplejehistorie (f.eks. Dock og Stewart 1938). Her refererer begrebet helt specielt til forholdene i England ved reformationen, hvor klostrene øjeblikkeligt blev lukket og nonnerne fordrevet uden iværksættelse af et alternativ til omsorgen for samfundets 
syge og fattige. Så radikalt handlede reformatorerne ikke i Danmark, hvor klostrene dels afvikles i takt med at munkene og nonnerne døde og staten dels tog de sociale opgaver på sig i et vist omfang. Forskningen i feltet er i dansk sammenhæng yderst begrænset (Gøtzsche 2001).

7. Sankt Joseph Søstrenes af Chambéry blev grundlagt 1816 i Savoyen, som en af mange grene af de oprindelige Sankt Joseph Søstre, der 1646 blev grundlagt i Frankrig af jesuitten pater Jean-Pierre Médaille. Se f.eks. Werner (2002) for en nærmere beskrivelse af kongregationens grundlæggelse og etablering i de nordiske lande.

8. Oversat brev fra pastor Schürhoff til pastor Beckmann i Ösnabrück 3. marts 1857 (Sankt Joseph Søstrenes Arkiv i København (SJSAK) A: Den Danske Provins

9. Oversat brev fra pastor Schürhoff til ærkebiskoppen af Chambéry 18. september1857 (SJSAK: A: Den danske provins).

10. Oversat brev fra ærkebiskoppen af Chambéry til pastor Schürhoff 13. oktober 1857 (SJSAK: A: Den danske provins).

11. Oversat brev fra pastor Schürhoff til pastor Beckmann 3. marts 1857 (SJSAK: A: Den danske provins).

12. Sankt Josephs hospitalerne placering og virketid var: København 1875-1979, Fredericia 18791949, Århus 1900-72, Horsens 1900-68, Randers 1900-46, Odense 1901-68, Ålborg 1902-90, Esbjerg 1904-78. (Malchau 2003).

13. Sygehusenes tilhørsforhold, placering og virketid var: Kamillianerne, Ålborg 1900-83; Sankt Elisabeth Søstrene, København 1905-70 og Nrstved 1923-68; Visdomsdøtrene, Roskilde 1905-62; Maria Søstrene, Vejle 1913-94 og Svendborg 1922-66; Sankt Hedvig Søstrene, Aabenraa 192674 og Kolding 1929-75; Elisabethinerinderne, Holbæk 1931-74 (Malchau 2004).

14. Sankt Joseph Søstrenes sygeplejesøstre havde ved ankomsten til Danmark angiveligt en formel sygeplejeuddannelse. I ordenssamfundets regler fra 1600-tallet fremføres det, at sygepleje udføres efter forudgående instruktion. (SJS arkiv generalhuset Rom: "Original Documents" ). I Nordisk Kirketidende 1880 fremhæves søstrenes uddannelse i artiklen "Katholsk Sygepleie". Se også: Malchau 1998. 15. Sankt Joseph Søstrenes har f.eks. etableret retrætecentre med tilbud om åndelig vejledning for søgende mennesker uafhængig af kirkesamfund og religion. Se f.eks. interview med søster Emma Martensen i Kristeligt Dagblad (Remar 2001). 16. I 1913 var der f.eks. en følelsesladet langvarig polemik i Ålborg i forbindelse med, at en ung lutheransk pige påtænkte at blive nonne efter ind læggelse på Sankt Joseph Søstrenes sygehus (Nordisk Ugeblad 1913).

17. Notat af overlæge Hansborg 7. juni 1936 "Angaaende dannelse af 'Foreningen af Lxger ved katolske Hospitaler' og 'Centralraadet'”, dokument december 1935 vedr. grundlæggelsen af Centralraadet for den katolske Hospitalsvirksomhed i Danmark og Vedtægter for Vikariatets Hospitalsudvalg 11. januar 1949 (Katolsk Historisk Arkiv i Danmark - 1060,00 Hjælpeinstitutioner generelt). 18. Frandsen var medicinaldirektør1927-1961. Hans holdning til de religiøse sygehuse kom til udtryk i pressen. I hans erindringer undlader han at omtale dem og det kan undre! (Frandsen 1966).

\section{LITTERATUR}

- Bondesen, Peter, Lars Skov Henriksen og Anja Jørgensen (2001): Filantropi, selvhjalp og interesseorganisering, Odense Universitetsforlag, Odense. - Carey, Ann (1997): Sisters in Crisis, Our Sunday Visitor, Indiana

- Constitutioner for Sanct Josephs-Søstrenes Ordensamfund (1878): Berlingske Bogtrykkeri, Kjøbenhavn.

- De Beauregard, E. Costa (1944). Kronik over St. Joseph-Søstrenes Ordenssamfund af Chambéry, St. Joseph-Søstrenes Provinsialhus København, København.

- De kvindelige ordenssamfund i Danmark (2001): Ansgarstiftelsens Forlag, København.

- Dock, Lavinia L. og Isabel M. Stewart (1938): $A$ Short History of Nursing, Putman's Sons, New York/London.

- Frandsen, Johannes (1966): Dr. Frandsens erindringer, Nyt Nordisk Forlag Arnold Busck, København.

- Gøtzsche, Inger og Karen Nygaard (1993): Sygeplejens udvikling og kulturbistoriske baggrund, Nyt Nordisk Forlag Arnold Busck, København.

- Gøtzsche, Inger (2001): Klostervasen og sundhedsvesen i Danmarks og Europas middelalder, C.A. Reitzel, København.

- Hauge, Svend (1963): I Troskab mod Kaldet. Den danske Diakonissestiftelse 1863-1963, Missionstrykkeriet, København.

- Politiken (1934): "Ikke flere katolske hospitaler i Danmark", 9. november.

- Katholsk Haandbog for Danmark (1943): Sankt Ansgars Forlag, København.

- Katolsk håndbog for Danmark (1983): Ansgarstiftelsens Forlag, København. 
Katolsk Ugeblad (1940): "Danmarks katolske Sygeplejerske-Forbund", (31) 496-97.

- Lausten, Martin Schwartz (1987): Danmarks Kirkehistorie, Gyldendal, København.

- Malchau, Susanne (1998): Karlighed er tjeneste. Soster Benedicte Ramsing - en biografi, Dansk Sygeplejeråd, København.

- Malchau, Susanne (2003): "Sankt Joseph hospitalerne i Danmark 1875-1990", Bibliotek for Lager 195(3): 135-75.

- Malchau, Susanne (2004): "Women Religious and Protestant Welfare: The Sisters of Saint Joseph's Empire of Catholic Hospitals in Denmark", in: Werner, Yvonne Maria (red.), Nuns and Sisters in the Nordic Countries after the Reformation, Studio Missionalis Svecana XC, Uppsala, p. $107-$ 48 .

- Malchau, Susanne and Else-Britt Nilsen (2004): "Appendix. Tables and Figures" in: Werner, Yvonne Maria (red.), Nuns and Sisters in the Nordic Countries after the Reformation, Studio Missionalis Svecana XC, Uppsala, p. 419-36.

- Malmgart, Liselotte (1996). Diakonisyn og diakoniuddannelse på Kolonien Filadelfia 1897-1987, Institut for diakoni og sjælesorg.

- Malmgart, Liselotte (2000): Med gladen som verktøj. Diakonissehuset Sankt Lukas Stiftelsen 1900-2000, Diakonissehuset Sankt Lukas Stiftelsen, Holbæk.

- Medicinalberetninger i Danmark 1900-1970.

- Nelson, Sioban (2001): Say Little do Much. Nurses, Nuns and Hospitals in the Nineteenth Century, University of Pennsylvania Press, Philadelphia.

- Nilsen, Else-Britt (2001): Nonner $i$ storm og stille. Katolske ordenssøstre $i$ Norge $i$ det 19. og 20. årbundre, Solum Forlag, Oslo.

- Nordisk Kirketidende for katholske Kristne (1880): "Katholsk Sygepleie", (18) 279.

- Nordisk Ugeblad for katholske Kristne (1913):

"Norden for Lands Lov og Ret.", (39) 676-83.

. Remar, Dorte (2001). "Ind i stilheden". Kristeligt Dagblad, 19. oktober, s. 9-10.

- Vallgårda, Signild (1985): Sjukhus og fattigpolitik - Et bidrag til de danska sjukhusens historia 1750-

1880, FADL's Forlag, København.

- Werner, Yvonne Maria (2002): Kvinnlig motkultur och katolsk mission. Sankt Josefsystrarna i Danmark och Sverige 1856-1936, Veritas Förlag,

Stockholm.

- Werner, Yvonne Maria (red.) (2004): Nuns and Sisters in the Nordic Countries after the Reformation, Studio Missionalis Svecana XC, Uppsala.

\section{SUMMARY}

The article gives a statistical overview and confessional perspectives on the female Catholic nursing-orders in Denmark from 1856 to the present. In focus are the Catholic orders which to some extend are compared to the Protestant deaconesses of the country. The background is that in Denmark in 1849 the Danish Constitution introduced freedom of worship, and in 1856 the first Catholic nursing-order settled in Denmark. Today 27 different female catholic orders/congregations have been or still are in Denmark. Ten of these orders were nursing-orders and six of them, comprising 90 percent of the Catholic sisters in Denmark, opened 16 general hospitals in the period 1875-1931. Within these hospitals they made their greatest contribution to Danish society between 1920 and 1940, when numbered 537-775 sisters and owning ten percent of the hospital beds in Denmark. The deaconesses comprised a similar amount of sisters and they owned two percent of the hospital beds. The deaconesses were Danish but the Catholic sisters came from abroad. Consequently, they had cultural ballast in terms of another nationality and an approach to Christianity, which differed from the Danish Lutheranism. The encounter between these two cultures was not always friendly, as the sisters were facing a society where the general opinion was that Catholicism was dangerous. The lack of vocations and the development of the Danish welfare state 1930-1970 by and large ended the Catholic nursing-orders hospitals. Despite the fact that they were a significant part of the Danish welfare project, they have never been included in the Danish history.

Susanne Malchau, cand.cur., ph.d. lektor i sygepleje på Aarhus Universitet 